\title{
FGFR3 NP_000133.1:p.G370C
}

National Cancer Institute

\section{Source}

National Cancer Institute. FGFR3 NP 000133.1:p.G370C. NCI Thesaurus. Code C128913.

A change in the amino acid residue at position 370 in the fibroblast growth factor receptor 3 protein where glycine has been replaced by cysteine. 